\title{
The influence of severity and time of foliar damage on yield and fruit quality in apple (Malus domestica Borkh.)
}

\author{
S.A. Bound \\ Tasmanian Institute of Agriculture, University of Tasmania, Hobart, Tasmania, Australia
}

\begin{abstract}
Summary
Leaf damage/defoliation caused by pests or phytotoxic damage following chemical application can result in loss of leaf area at any time during the growing season. Four trials were conducted to examine the impact of severity and time of foliar damage on fruit set and quality in apple. Trees tolerated light to moderate leaf damage throughout the season with no significant effect on fruit set and thus crop load. Where $\mathbf{7 5 \%}$ or more of the leaf surface was lost, fruit set was reduced and fruit quality was affected. Complete loss of leaves up to three weeks after full bloom (wAFB) resulted in very low or no fruit set, but from 9 wAFB crop load was not affected by leaf damage. Loss of terminal shoot leaves had no effect on fruit set, but spur leaves were critical early in the season with the impact lessening from 6 wAFB. This study has demonstrated that low levels of foliar damage have little effect on fruit size or quality, but high levels can impact on both set and quality. Fruit quality was reduced following leaf damage during the period 6-12 weeks after full bloom which is the critical period for cell division in the fruit as well as flower initiation for the following year. High levels of leaf damage also reduced fruit size in spite of reduced crop load levels, most likely the result of a reduction in carbohydrate assimilation during the cell division phase of fruit development.
\end{abstract}

Keywords

desiccant, leaf area, phytotoxicity, crop load, fruit set

\section{Introduction}

Leaf damage/defoliation caused by pests such as mites or disease (e.g., powdery mildew) or by phytotoxic damage following pesticide application can result in loss of leaf area at any time during the growing season. In particular, desiccating chemicals applied as blossom thinners during the flowering period can cause necrosis of leaves, resulting in reduced leaf area (Bound and Jones, 2004). Although damage is usually restricted to slight marginal necrosis of the leaves when these chemicals are applied at the recommended label rates, many growers have questioned the impact of reduced leaf area on fruit quality. Kon et al. (2013) also reported a lack of improvement in fruit size and return bloom following severe leaf damage with a mechanical string thinner.

For optimal fruit set, growth and quality, the importance of healthy spur leaves early in the season has been described by Proctor and Palmer (1991). Loss of leaf area after flowering has also been shown to reduce return bloom and fruit set the following year (Davis et al., 2000).

\section{Significance of this study}

What is already known on this subject?

- Healthy spur leaves are important for optimal fruit set, growth and quality, especially early in the season. For dwarfing rootstocks the optimal leaf:fruit ratio is $10: 1$, and a higher ratio is required for more vigorous rootstocks.

\section{What are the new findings?}

- Light to moderate leaf damage throughout the season had no effect on fruit set, size or quality. Fruit quality was reduced following moderate (50\%) to high leaf damage 6-12 weeks after flowering. Seeds are important for fruit retention when resources are low.

What is the expected impact on horticulture?

- Application of desiccants for crop thinning is a safe practice as the level of leaf damage at label rates has no impact on fruit set or quality.

Many researchers have discussed the issue of phytotoxicity when using desiccating chemicals. Irving et al. (1989) found that high rates of ammonium thiosulphate (ATS) caused severe scorching of flowers, leaves and meristems. The chemical Armourthin ${ }^{\circledR}$ (Akzo Nobel) has been shown to cause leaf burn and shoot dieback (Southwick et al., 1996). Bound and Jones (1997) suggested that excessive foliar damage following application of desiccating chemicals during flowering is likely to affect fruit size.

Several studies relating to foliar feeding by pests throughout the season have shown that leaf damage can impact on fruit size (Zwick et al., 1976; Ames et al., 1984; Beers et al., 1987; Francesconi et al., 1996; Lakso et al., 1996), firmness (Zwick et al., 1976) and sugar content (Ames et al., 1984), but there is a lack of information available on the impact of foliar damage on fruit maturity and other quality characteristics.

The series of trials reported here examined the impact of leaf damage on crop load, fruit quality and return bloom by simulating leaf damage from flowering through to 18 weeks after bloom.

\section{Materials and methods}

Four trials were conducted at the Grove Research Station in the Huon Valley, Tasmania, Australia $\left(43^{\circ} 07^{\prime} \mathrm{S}, 147^{\circ} 01^{\prime} \mathrm{E}\right)$ over four consecutive years. All trees were situated in the same orchard block on a sandy loam soil. Cultivar, rootstock and tree age for each trial are described in Table 1 . Trees in each trial were approximately $2 \mathrm{~m}$ in height, trained to a central axis system and spaced at $4 \mathrm{~m}$ between and $2 \mathrm{~m}$ within rows, with an east-west row orientation. 
TABLE 1. Details on trees used in each trial.

\begin{tabular}{lccc}
\hline & Cultivar & Rootstock & Age (years) \\
\hline Trial 1 & Oregon Spur 'Delicious' & MM106 & 9 \\
Trial 2 & Oregon Spur 'Delicious' & Seedling & 14 \\
Trial 3 & 'Royal Gala' & MM106 & 5 \\
Trial 4 & 'Royal Gala' & M1 with Fuji interstem & 4 \\
\hline
\end{tabular}

For all trials, trees were selected in early spring of each year based on uniformity of size and vigour. Trunk girths were measured $10 \mathrm{~cm}$ above the graft union to calculate the trunk cross-sectional areas (TCSA). Blossom clusters were counted on each tree and blossom density (number of blossom clusters $\mathrm{cm}^{-2}$ TCSA) determined. Trees were then blocked into five blossom density groups in Trials 1 and 4, six blossom density groups in Trial 2 and four blossom density groups in Trial 3. Treatments were allocated at random to single tree plots within each block, giving five replicates per treatment in Trials 1 and 4, six replicates in Trial 2 and four replicates in Trial 3.

\section{Treatments}

Treatments involved reduction of leaf area to varying degrees $(0-100 \%)$ to simulate leaf damage; each treatment was applied to the whole tree. In simulating $100 \%$ damage (equivalent to complete defoliation) the entire leaf blade was removed by cutting through the petiole. All other treatments involved removal of a portion of the leaf blade to simulate damage; this was done by cutting the apical section of the blade with scissors, the leaf area removed was an estimate based on the proportion of blade removed.

1. Trial 1. Consisted of removal of either 0 (control), 50 or $100 \%$ of entire leaves. Treatments were applied at full bloom (FB).

2. Trial 2. Treatments consisted of removal of $0,20,40,60$, 80 , or $100 \%$ of the leaf blade, removal of whole spur leaves, or removal of terminal shoot whole leaves. All treatments were applied at FB.

3. Trial 3. Treatments were a factorial combination of degree of leaf damage $(25,50,75$, or $100 \%$ of the leaf blade removed, or removal of spur/bourse shoot leaves) applied at three different times (FB, 1 week after FB [wAFB] or 2 wAFB), plus an untreated control.

4. Trial 4. Treatments were a factorial combination of degree of leaf damage $(25,50,75$, or $100 \%$ of the leaf blade removed, or removal of spur/bourse shoot leaves) applied at seven different times throughout the growing season (FB, 3 wAFB, 6 wAFB, 9 wAFB, 12 wAFB, 15 wAFB, or 18 wAFB), plus an untreated control.

\section{Assessments}

Fruit was harvested at standard commercial maturity in March of each season for all trials. The 'Delicious' trees (Trials 1 and 2) were strip picked according to normal commercial practice. Total numbers of fruit per tree were counted and weighed, and mean fruit weight calculated for each tree. The 'Gala' trees in Trial 3 were selectively picked, based on colour, with three picks in total. Number of fruit from each pick was recorded and added together to give total number of fruit per tree. The percentage of fruit harvested at first pick was calculated. In Trial 4, the 'Gala' trees were strip picked as maturity was relatively even. In all trials, the total fruit number on each tree was used to calculate two crop load variables, number of fruit $\mathrm{cm}^{-2}$ TCSA and number of fruit per 100 blossom clusters.

Fruit was graded on a commercial size grader and 28 fruit selected randomly from the $60-75 \mathrm{~mm}$ size range for each replicate. Fruit were examined for shape, total soluble solids (TSS) content, fruit flesh firmness and seed number. Starch content and fruit background colour were measured in 'Gala' fruit in Trials 3 and 4.

Fruit shape was determined by measuring the length (L) and diameter (D) of the fruit using a Vernier calliper and calculating L/D ratios. Flesh firmness was measured on pared flesh with a Mecmesin AFG250 force gauge fitted with an Effegi $11 \mathrm{~mm}$ penetrometer probe connected to a Mecmesin $2500 \mathrm{E}$ motorised stand operating at a speed of $0.65 \mathrm{~cm} \mathrm{~s}^{-1}$. Juice expressed from the apples during the firmness measurements was collected and TSS concentration ( ${ }^{\circ}$ Brix) was assessed with an Atago PR-1 digital refractometer.

The number of fully developed seeds was determined by slicing fruit horizontally through the equatorial plane and counting the viable seeds. To determine starch pattern index (SPI), the cut surface of the calyx bearing half of each fruit was dipped in iodine solution and SPI assessed according to the six point index as described by Little (1999); the higher the SPI the lower the percentage of starch present. Fruit background colour was measured visually using the scale presented by Frappell and O'Loughlin (1962).

To determine return bloom, blossom clusters were counted on each tree during the spring following treatment and blossom density calculated.

\section{Data analysis}

Data were subjected to analysis of variance using Genstat 17.1 (VSN International Ltd., U.K.). Data are presented as mean values for each treatment combination or main effect. Results described as significant were at a probability level of $\mathrm{P}=0.05$ and Fisher's least significant difference (LSD) $(\mathrm{P}=0.05)$ was used for comparison of treatment means. Graphs were plotted using SigmaPlot 13.0 (Systat Software Inc.).

To enable an understanding of the relevance of the results obtained in relation to commercial situations, in trials using the cultivar 'Delicious', crop load and fruit weight/size results were related to commercial target levels as described by Koen et al. (1988).

\section{Results}

\section{Trial 1 - Oregon Spur 'Delicious'}

Crop load in this trial was relatively low (Table 2), with fruit number $\mathrm{cm}^{-2}$ TCSA on the controls falling within the target crop load range, and fruit number/100 blossom clusters being below the target crop load range. Both crop load variables were significantly reduced by the $100 \%$ leaf removal treatment, while the $50 \%$ treatment had no effect compared with the control. Mean fruit weight was reduced significant- 
TABLE 2. The effect of level of simulated leaf damage on crop load, mean fruit weight, return bloom, fruit shape (length/ diameter ratio), total soluble solids content, firmness and seed number of 'Delicious' apple (Trial 1). Treatments were applied at full bloom. TCSA = trunk cross-sectional area.

\begin{tabular}{|c|c|c|c|c|}
\hline Treatment & $\begin{array}{l}\text { No. fruit } \mathrm{cm}^{-2} \\
\text { TCSA }\end{array}$ & $\begin{array}{l}\text { No. fruit per } 100 \\
\text { blossom clusters }\end{array}$ & $\begin{array}{l}\text { Mean fruit weight } \\
\text { (g) }\end{array}$ & $\begin{array}{c}\text { Return bloom } \\
\text { (buds } \mathrm{cm}^{-2} \mathrm{TCSA} \text { ) }\end{array}$ \\
\hline Control & $3.93 \mathrm{~b}$ & $25 b$ & $181 \mathrm{~b}$ & $18 b$ \\
\hline $50 \%$ leaf removal & $3.59 \mathrm{~b}$ & $24 b$ & $184 b$ & $8 a$ \\
\hline $100 \%$ leaf removal & $0.27 \mathrm{a}$ & $2 a$ & $106 \mathrm{a}$ & $19 b$ \\
\hline Commercial target levels & $2-4$ & $40-60$ & 150 & \\
\hline Treatment & $\begin{array}{l}\text { Length/diameter } \\
\text { ratio }\end{array}$ & $\begin{array}{c}\text { Total soluble solids } \\
\text { ( }{ }^{\circ} \text { Brix) }\end{array}$ & $\begin{array}{l}\text { Fruit flesh firmness } \\
(\mathrm{kg})\end{array}$ & $\begin{array}{c}\text { Average number seeds } \\
\text { per fruit }\end{array}$ \\
\hline Control & $0.985 \mathrm{~b}$ & $13.46 \mathrm{a}$ & $11.34 \mathrm{a}$ & $4.8 \mathrm{a}$ \\
\hline $50 \%$ leaf removal & $0.980 \mathrm{~b}$ & $13.49 \mathrm{a}$ & $11.42 \mathrm{a}$ & $4.9 \mathrm{a}$ \\
\hline $100 \%$ leaf removal & $0.962 \mathrm{a}$ & $13.95 b$ & $11.78 b$ & $7.6 \mathrm{~b}$ \\
\hline
\end{tabular}

Within each column, means followed by different letters are significantly different according to the LSD means comparison test at $P=0.05$.

ly by the $100 \%$ defoliation treatment compared with the control. Fruit in both the control and 50\% defoliation treatments were above the commercial target level for mean fruit weight, but fruit from the $100 \%$ defoliation treatment was below the target level. Return bloom was significantly lower in the $50 \%$ treatment than in the control or $100 \%$ treatment.

Fruit L/D ratio (Table 2) was significantly reduced by the $100 \%$ treatment compared with the other two treatments, but TSS, fruit firmness and seed number were significantly higher in the $100 \%$ treatment than in both the control and $50 \%$ treatment.

\section{Trial 2 - Oregon Spur 'Delicious'}

Compared with the control, the only treatments to significantly reduce crop load were the $100 \%$ leaf removal and the spur leaf treatment (Table 3). Crop loads were above the commercial target range for all treatments except for the $100 \%$ defoliation and spur leaf treatments compared with the untreated control. Return bloom was low in all treatments, with only 2.5 buds $\mathrm{cm}^{-2}$ TCSA in the control (Table 3), but $100 \%$ leaf removal had significantly greater return bloom than the control. Mean fruit weight was significantly increased in the $20 \%, 60 \%, 80 \%, 100 \%$ and spur leaf treatments. Fruit TSS content was significantly increased by most leaf removal treatments, however the $40 \%$ treatment reduced TSS content, while $100 \%$ defoliation had no effect. Removal of spur leaves resulted in the greatest increase in TSS content. All treatments significantly reduced fruit firmness compared with the control, with the exception of the $100 \%$ treatment.

TABLE 3. The effect of level of simulated leaf damage on crop load, return bloom, fruit weight, soluble solids content and firmness of 'Delicious' apple (Trial 2). Treatments were applied at full bloom. TCSA = trunk cross-sectional area.

\begin{tabular}{|c|c|c|c|}
\hline Treatment & $\begin{array}{l}\text { No. fruit } \mathrm{cm}^{-2} \\
\text { TCSA }\end{array}$ & $\begin{array}{l}\text { No. fruit per } 100 \\
\text { blossom clusters }\end{array}$ & $\begin{array}{l}\text { Return bloom } \\
\text { (buds } \mathrm{cm}^{-2} \text { TCSA) }\end{array}$ \\
\hline Control & $6.46 \mathrm{~cd}$ & $84 \mathrm{c}$ & $2.5 \mathrm{ab}$ \\
\hline $20 \%$ leaf removal & $7.13 d$ & $76 c$ & $3.6 a b$ \\
\hline $40 \%$ leaf removal & $5.75 \mathrm{bcd}$ & $63 \mathrm{bc}$ & $1.6 \mathrm{a}$ \\
\hline $60 \%$ leaf removal & $5.67 \mathrm{bcd}$ & $60 \mathrm{bc}$ & $1.1 \mathrm{a}$ \\
\hline $80 \%$ leaf removal & $4.59 \mathrm{bc}$ & $67 b c$ & $2.9 a b$ \\
\hline $100 \%$ leaf removal & $1.09 \mathrm{a}$ & $12 \mathrm{a}$ & $8.6 \mathrm{c}$ \\
\hline Spur leaf removal & $3.63 b$ & $36 a b$ & $6.2 \mathrm{bc}$ \\
\hline Terminal leaf removal & $7.09 \mathrm{~d}$ & $67 \mathrm{bc}$ & $1.4 \mathrm{a}$ \\
\hline Commercial target levels & $2-4$ & $40-60$ & \\
\hline Treatment & $\begin{array}{l}\text { Mean fruit weight } \\
\text { (g) }\end{array}$ & $\begin{array}{l}\text { Total soluble solids } \\
\left({ }^{\circ} \text { Brix }\right)\end{array}$ & $\begin{array}{l}\text { Fruit flesh firmness } \\
\qquad(\mathrm{kg})\end{array}$ \\
\hline Control & $106 a$ & $13.48 \mathrm{~b}$ & $7.61 \mathrm{~d}$ \\
\hline $20 \%$ leaf removal & $134 \mathrm{bcd}$ & $13.82 \mathrm{de}$ & $7.24 \mathrm{ab}$ \\
\hline $40 \%$ leaf removal & $113 \mathrm{ab}$ & 13.27 a & $7.20 \mathrm{a}$ \\
\hline $60 \%$ leaf removal & $144 \mathrm{~cd}$ & $13.67 \mathrm{~cd}$ & $7.23 \mathrm{ab}$ \\
\hline $80 \%$ leaf removal & $148 \mathrm{~cd}$ & $13.78 \mathrm{~cd}$ & $7.40 \mathrm{bc}$ \\
\hline $100 \%$ leaf removal & $140 \mathrm{~cd}$ & $13.64 \mathrm{bc}$ & $7.53 \mathrm{~cd}$ \\
\hline Spur leaf removal & $156 d$ & $14.17 f$ & $7.29 \mathrm{ab}$ \\
\hline Terminal leaf removal & $126 a b c$ & 13.97 e & $7.12 \mathrm{a}$ \\
\hline Commercial target levels & 150 & & \\
\hline
\end{tabular}

Within each column, means followed by different letters are significantly different according to the LSD means comparison test at $\mathrm{P}=0.05$. 
TABLE 4. The effect of (i) level and (ii) time of leaf damage on number of fruit/100 blossom clusters, mean fruit weight, return bloom, percentage of fruit harvested at first pick and fruit shape (length/diameter ratio) of 'Royal Gala' apples (Trial 3). Treatments were a factorial combination of time and level of damage; as there were no interactions between the two factors, only the main effects are shown. TCSA = trunk cross-sectional area; FB = full bloom; wAFB = weeks after FB; L/D = length/ diameter.

\begin{tabular}{lccccc}
\hline & $\begin{array}{c}\text { No. fruit per 100 } \\
\text { blossom clusters }\end{array}$ & $\begin{array}{c}\text { Mean fruit weight } \\
(\mathrm{g})\end{array}$ & $\begin{array}{c}\text { Return bloom } \\
\text { (buds cm }{ }^{-2} \mathrm{TCSA} \text { ) }\end{array}$ & $\begin{array}{c}\text { \% fruit harvested } \\
\text { at first pick }\end{array}$ & Fruit L/D ratio \\
\hline $\begin{array}{l}\text { (i) Level of leaf damage } \\
0 \% \text { (control) }\end{array}$ & $146 \mathrm{c}$ & $120 \mathrm{a}$ & & & \\
$25 \%$ & $101 \mathrm{~b}$ & $118 \mathrm{a}$ & $4.2 \mathrm{a}$ & $44 \mathrm{bc}$ & $0.888 \mathrm{c}$ \\
$50 \%$ & $99 \mathrm{~b}$ & $125 \mathrm{ab}$ & $4.5 \mathrm{a}$ & $32 \mathrm{ab}$ & $0.889 \mathrm{c}$ \\
$75 \%$ & $70 \mathrm{~b}$ & $141 \mathrm{c}$ & $4.1 \mathrm{a}$ & $25 \mathrm{a}$ & $0.869 \mathrm{a}$ \\
$100 \%$ & $3 \mathrm{a}$ & $134 \mathrm{bc}$ & $7.4 \mathrm{~b}$ & $56 \mathrm{c}$ & $0.879 \mathrm{~b}$ \\
Spur/bourse & $70 \mathrm{~b}$ & $140 \mathrm{c}$ & $13.5 \mathrm{c}$ & $100 \mathrm{~d}$ & - \\
\hline (ii) Time of damage & & & $9.8 \mathrm{~b}$ & $51 \mathrm{c}$ & $0.894 \mathrm{c}$ \\
FB & 89 & 131 & & & 49 \\
1 wAFB & 74 & 132 & $8.4 \mathrm{~b}$ & 52 & 0.883 \\
2 wAFB & 80 & 125 & $7.1 \mathrm{ab}$ & 53 & 0.887 \\
\hline
\end{tabular}

Within each column/main effect, means followed by different letters are significantly different according to the LSD means comparison test at $P=0.05$

\section{Trial 3 - 'Royal Gala'}

Level of leaf damage had a significant effect on crop load, mean fruit weight, return bloom, \% fruit harvested at first pick and fruit L/D ratio (Table 4). Compared with the control, number of fruit/100 blossom clusters was significantly reduced at all levels of leaf damage, with the greatest reduction observed with complete defoliation. Mean fruit weight was significantly higher at $75 \%$ and $100 \%$ damage and spur/bourse leaf removal compared to the other three levels of damage. Complete defoliation resulted in a significantly higher percentage of fruit harvested at first pick than in any other treatment, but $50 \%$ defoliation reduced the amount of fruit harvested at first pick compared with the control and $75 \%$ defoliation treatments. Fruit L/D ratio was significantly lower in the $50 \%$ and $75 \%$ defoliation treatments compared with all other treatments. As fruit set was extremely low in the $100 \%$ defoliation treatments, there was insufficient fruit available for analysis of fruit quality parameters for these treatments.

Time of leaf damage had a significant effect on return bloom (Table 4), but not on any other parameters assessed. Return bloom was lower in the 2 wAFB treatments than the FB treatments.

There were no significant interactions between level and time of damage for number of fruit/100 blossom clusters, mean fruit weight, $\%$ fruit $\geq 75 \mathrm{~mm}$ diameter, return bloom, $\%$ fruit harvested at first pick or fruit L/D ratio (results not presented). Interactions for all other parameters examined (number of fruit $\mathrm{cm}^{-2}$ TCSA, TSS, fruit firmness, seed number, background skin colour, starch index) were significant (Figure 1).

Compared with the control, the number of fruit $\mathrm{cm}^{-2}$ TCSA was significantly reduced by $75 \%$ and $100 \%$ defoliation at all times and by removal of spur/bourse leaves at FB (Figure 1a). Loss of spur/bourse leaves at FB resulted in significantly lower crop load than loss at 1 or 2 wAFB. The $100 \%$ defoliation treatments at 1 and 2 wAFB resulted in complete loss of crop, while at FB crop load was significantly lower than at other rates of defoliation.

Fruit TSS content was significantly higher in the spur/ bourse leaf defoliation treatments than in the control (Figure 1b). The $75 \%$ defoliation treatments at 1 and 2 wAFB also increased fruit TSS levels significantly compared with the control. Fruit TSS levels were significantly lower than the control in all 25\% treatments and in the 1 wAFB 50\% treatment.

There was a significant increase in fruit firmness compared with the control following $75 \%$ defoliation at 1 and $2 \mathrm{wAFB}$, and $50 \%$ defoliation treatment at 2 wAFB. (Figure $1 \mathrm{c})$. Firmness was significantly lower than the control in the $75 \% \mathrm{FB}$ and spur/bourse FB and 1 wAFB treatments.

Compared with the control, seed number was significantly reduced by $25 \%$ defoliation 2 wAFB, but was significantly higher in the $75 \% \mathrm{FB}$ and the spur/bourse FB and 1 wAFB treatments (Figure 1d).

Background colour was greener in all $25 \%$ defoliation treatments and the $75 \% \mathrm{FB}$ treatment than in the control (Figure 1e). The 75\% 1 wAFB and 1 and 2 wAFB spur/bourse treatments all resulted in significantly yellower fruit than the control. At 2 wAFB, higher levels of leaf removal resulted in yellower fruit. There was no significant effect on fruit skin background colour with $50 \%$ defoliation at all times or $75 \%$ at 2 wAFB compared with the control.

Only one treatment, $25 \%$ defoliation at 2 wAFB, resulted in a significantly lower starch index than the control (Figure 1f). Removal of spur/bourse leaves at both 1 and 2 wAFB significantly increased the starch index compared with the control, as did $25 \%$ and $75 \%$ defoliation at FB.

\section{Trial 4 - 'Royal Gala'}

There were significant interactions between level and time of leaf damage for crop load, mean fruit weight, fruit firmness, TSS, skin background colour and starch pattern index.

Both crop load variables, number of fruit per $\mathrm{cm}^{-2}$ TCSA (Figure 2a) and number of fruit per 100 blossom clusters (results not shown) showed similar patterns, with all FB and 3 wAFB reducing crop load below the level in the control, with the exception of the $25 \%$ defoliation 3 wAFB. The greater the level of defoliation at these times, the greater the reduction in crop load. At 6 wAFB both the $75 \%$ and $100 \%$ defoliations reduced crop load, while from 9 to 18 wAFB, only the $100 \%$ defoliation treatment reduced crop load below the level in the control. 
(a)

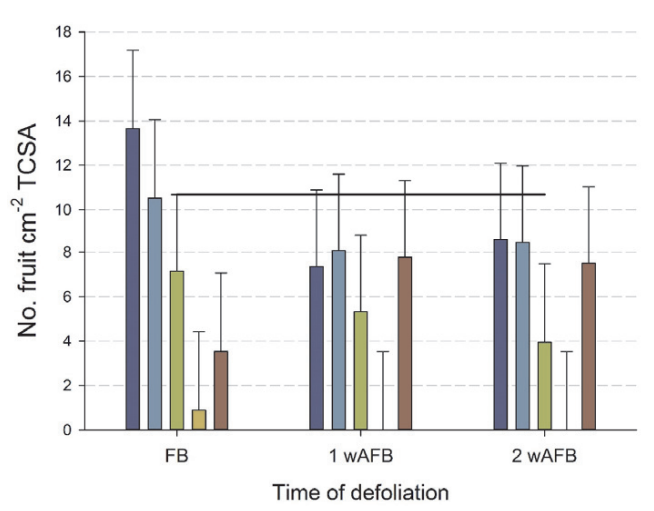

(c)

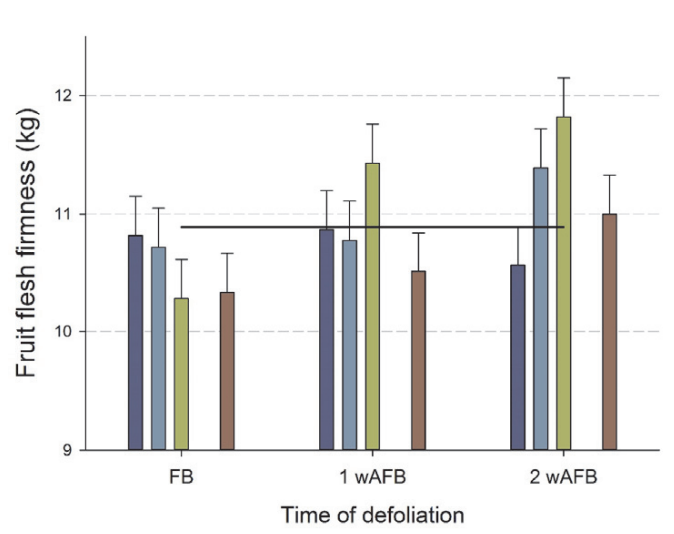

(e)

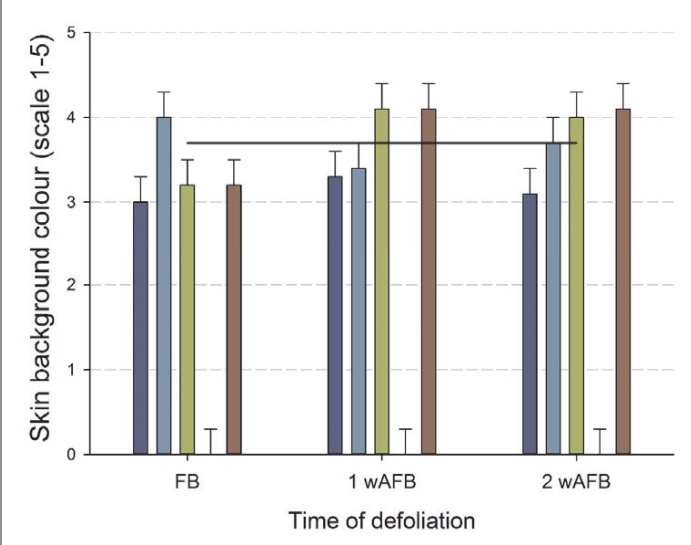

(b)

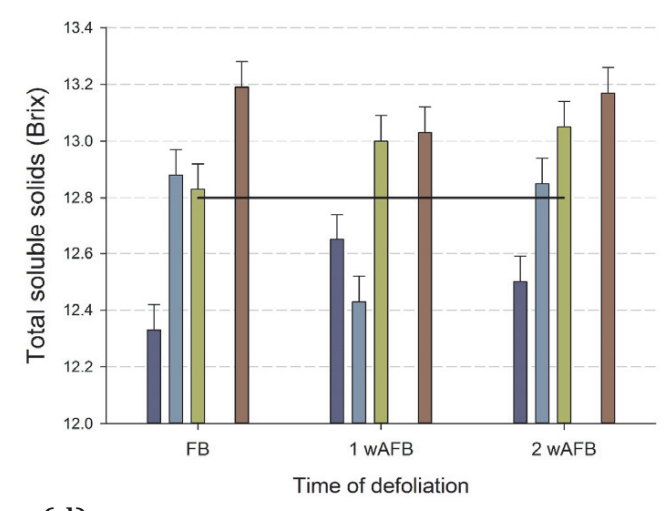

(d)

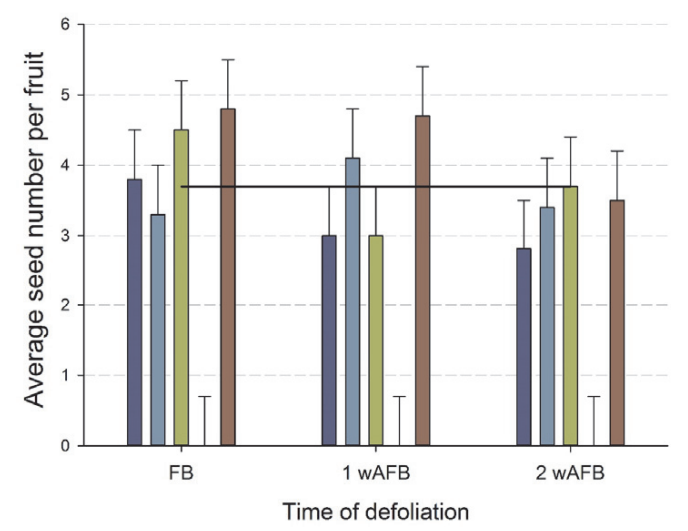

(f)

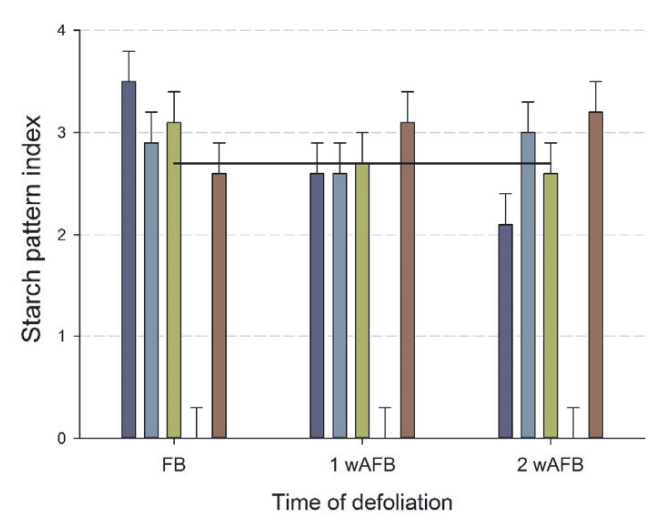

FIGURE 1. The interaction between level and time of simulated leaf damage in 'Royal Gala' apple on (a) crop load; (b) fruit total soluble solids content; (c) fruit flesh firmness; (d) seed number; (e) fruit skin background colour; and (f) fruit starch pattern index. TCSA = trunk cross-sectional area; FB = full bloom; wAFB = weeks after FB. Error bars represent least significant difference. Note that there were insufficient fruit available in the $100 \%$ defoliation to undertake fruit assessments.

Mean fruit weight (Figure 2b) was higher than the control in the FB and 3 wAFB treatments that showed reduced crop load levels. There was no effect on fruit weight in trees defoliated from 6 to 18 wAFB.

Fruit flesh firmness (Figure 2c) was reduced by the bourse defoliation treatment from FB to 6 wAFB, but there was no effect at or after 9 wAFB. The $100 \%$ defoliation at FB treatment resulted in the greatest reduction in fruit firmness compared with the untreated control and most other defoliation treatments.

Fruit TSS content was increased by all FB treatments compared with the untreated control (Figure 2d). As the sea- son progressed, TSS content reduced with increasing level of defoliation, but bourse leaf removal had little effect.

Defoliation early in the season resulted in an increase in fruit skin background colour, with yellower fruit at FB, closely followed by 3 wAFB (Figure 2e). At 9 wAFB both the $75 \%$ and $100 \%$ treatments delayed skin background colour development, while at 12 wAFB only the $100 \%$ defoliation treatment had this effect.

Hydrolysis of starch to sugar was delayed in most of the FB treatments compared with the control (Figure 2f), but from 6 wAFB most treatments showed increased starch hydrolysis. 
(a)

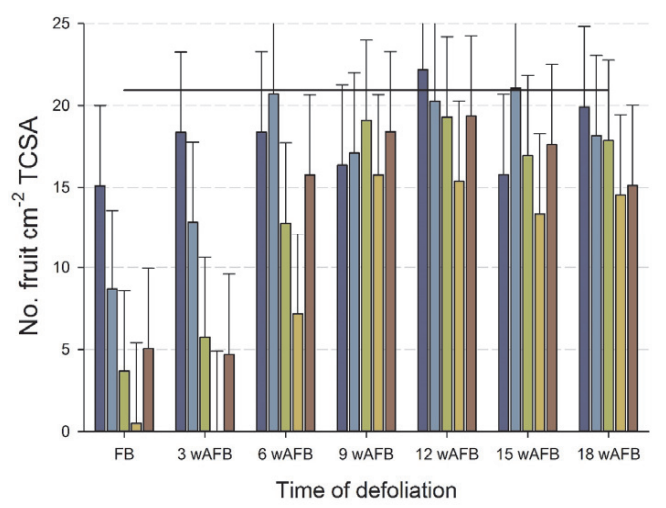

(c)

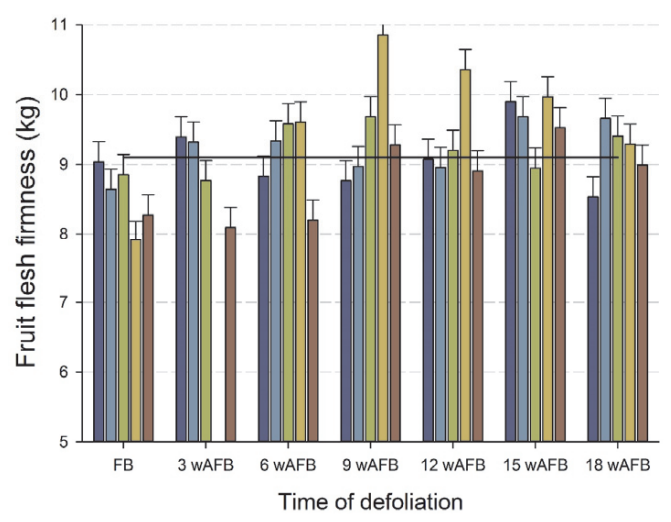

(e)

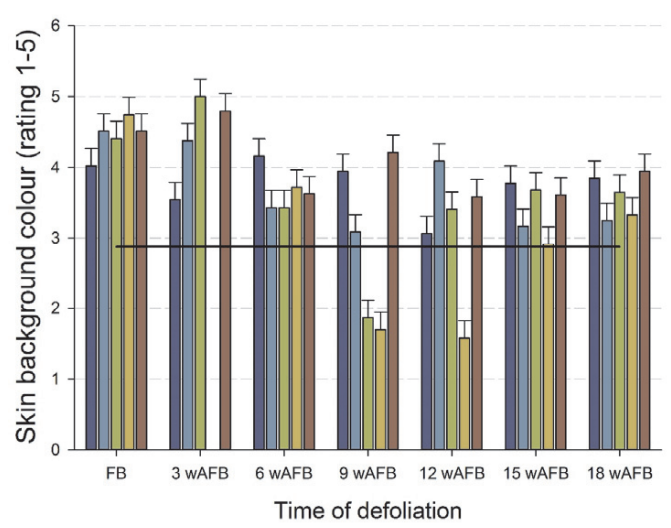

(b)

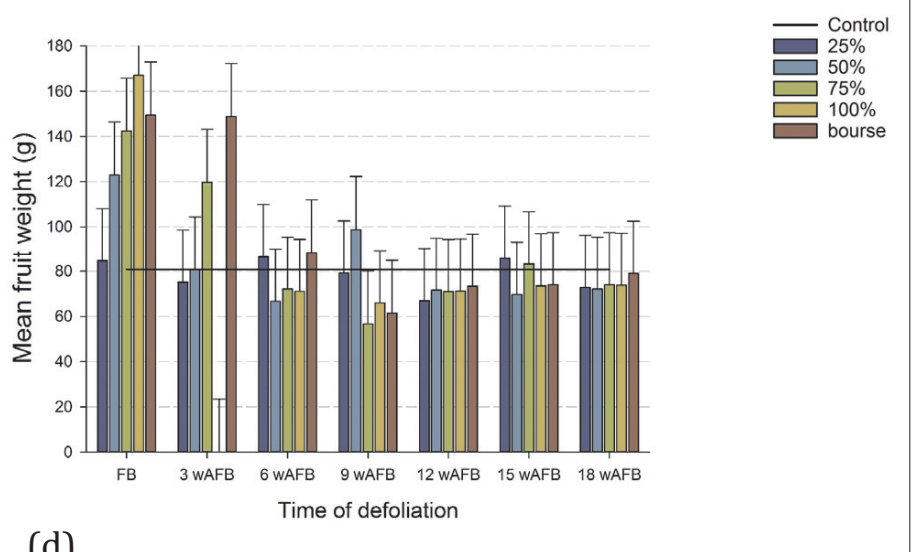

(d)

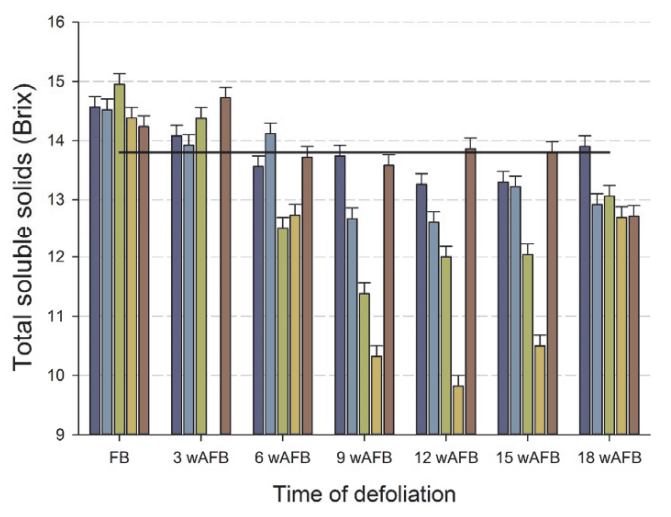

(f)

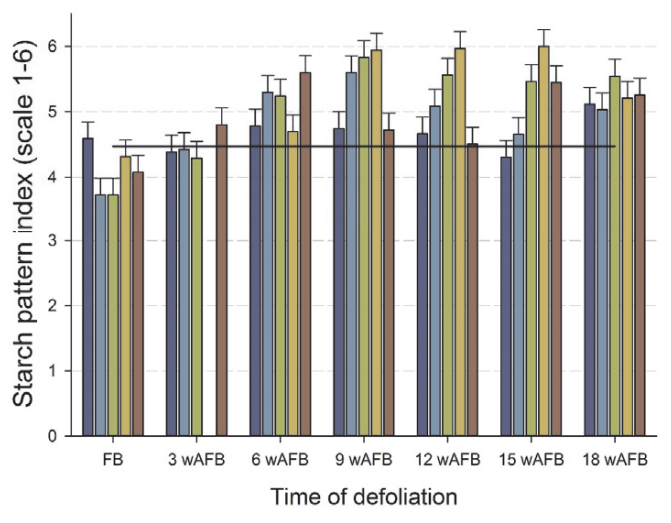

FiGURE 2. The interaction between level and time of simulated leaf damage 'Royal Gala' apple on (a) crop load; (b) mean fruit weight;(c) fruit flesh firmness; (d) fruit total soluble solids content; (e) fruit skin background colour; and (f) fruit starch pattern index. FB = full bloom; wAFB = weeks after FB. Error bars represent least significant difference.

Return bloom (Table 5) was least affected by defoliation at full bloom. Compared with the untreated control, all levels of defoliation reduced return bloom.

\section{Discussion}

This work has demonstrated that apple trees will tolerate light to moderate leaf damage throughout the season, particularly during the flowering period with no significant effect on fruit set and, thus, crop load. High levels of leaf damage $(\geq 75 \%)$ early in the season impacted on fruit quality, but low levels of damage had little effect.

Fruit set is influenced by the time that leaf damage oc- curs, as well as the degree of damage. Llewelyn (1968) reported an increase in fruit drop after petal-fall following defoliation at pink bud stage of flowering, but defoliation from 14 days AFB had no effect on fruit drop. It was concluded that only damage to spur leaves causes a reduction in crop load. In the work reported here, complete loss of leaves up to three weeks after full bloom resulted in very low or no fruit set in all trials, and even at 6 wAFB leaf loss impacted on crop load, but from 9 wAFB crop load was not affected by leaf damage. While loss of terminal shoot leaves had no effect on fruit set, spur leaves were shown to be critical, particularly early in the season up to 3 wAFB with the impact lessening 
TABLE 5. The effect of time and level of leaf damage on return bloom (buds $\mathrm{cm}^{-2}$ TCSA) of 'Royal Gala' apples (Trial 4). Treatments were a factorial combination of time and level of damage; as there were no interactions between the two factors, only the main effects are shown.

\begin{tabular}{lclc}
\hline Time of leaf damage & \multicolumn{2}{l}{ Level of leaf damage } \\
\hline FB & $17.0 \mathrm{c}$ & $0 \%$ (control) & $16.4 \mathrm{c}$ \\
3 wAFB & $8.0 \mathrm{ab}$ & $25 \%$ & $8.0 \mathrm{ab}$ \\
6 wAFB & $5.5 \mathrm{a}$ & $50 \%$ & $7.0 \mathrm{ab}$ \\
9 wAFB & $6.8 \mathrm{ab}$ & $75 \%$ & $5.4 \mathrm{a}$ \\
12 wAFB & $7.5 \mathrm{ab}$ & $100 \%$ & $8.7 \mathrm{ab}$ \\
15 wAFB & $11.2 \mathrm{~b}$ & Spur/bourse & $10.8 \mathrm{~b}$ \\
18 wAFB & $9.5 \mathrm{ab}$ & & \\
\hline
\end{tabular}

Within each column, means followed by different letters are significantly different according to the LSD means comparison test at $P=0.05$.

from 6 wAFB. This agrees with the conclusions of Ferree and Palmer (1982) that spur leaves on fruiting trees have an important localised influence on fruit set. Their work indicated that fruits are very dependent on leaves within the spur early in the season and are unable to receive photosynthate from elsewhere in the tree. However, Llewelyn (1963) found differences among apple cultivars, with 'Cox's Orange Pippin' and 'Worcester Pearmain' appearing much more dependent upon the spur leaves than 'Laxton's Superb'. Studying spray damage by lime-sulphur, Llewelyn $(1963,1966)$ concluded that the visible damage done to the spur leaves by two pre-blossom sprays of $2.5 \%$ lime-sulphur was insufficient to have any effect on fruit retention. This evidence, in conjunction with the results in the present work, suggests that the marginal burning of leaves frequently observed following application of desiccants for fruit thinning is unlikely to have any detrimental effects on fruit set.

Fruit weight is normally inversely related to crop load (Jones et al., 1992). However, following complete defoliation in this study, fruit weight did not increase in proportion to the reduced crop load observed. In trial 1, fruit weight was reduced following complete defoliation, while in subsequent trials, although there was an increase in fruit weight above that observed in the control, the expectation would have been for considerably heavier fruit considering the light crop loads. An explanation for this may be a reduction in production of assimilates as a result of reduced leaf:fruit ratio following defoliation. Although Proctor and Palmer (1991) and Spieser et al. (1999) reported no effect of early season defoliation on mean fruit weight, Lakso et al. (1996) reported reduced fruit growth rates in Starkrimson 'Delicious' trees following European red mite injury of leaves. According to Spieser et al. (1999), the earlier the peak of the mite population the greater the reduction in fruit size. The results reported in the present study suggest that complete loss of leaves and the associated lack of production of assimilates during the critical early cell division phase has a major impact on cell numbers within the fruit, and hence on final fruit weight at harvest. Combined with the impact on fruit set discussed above, complete loss of leaves during the flowering period had a marked effect on crop production with low yield and reduced fruit weights.

In this study, there was no effect on fruit weight or size at leaf loss levels of $50 \%$ early in the season. According to Priestley (1962), growing fruits use carbohydrates from regions of both synthesis and storage, hence carbohydrate is a limiting factor to fruit development. Early fruit growth, when leaf area is low, would be expected to be dependent on reserves, rather than on the current products of photosynthesis, as leaves only begin to balance demand with production when they reach about half their full size (Priestley, 1962). Martin et al. (1964) concluded that the major factor controlling cell numbers in apple fruits is the reserves available from the previous season. However, Quinlan (1966) showed that partial defoliation causes changes in the pattern of distribution of assimilates from the remaining leaves, compensating for the loss of part of the photosynthetic system; Baïram et al. (2019) also suggested that modification of the source:sink ratio seems to be compensated by an alteration of the photosynthetic rate of leaves. This would explain the lack of effect in this study of low levels of defoliation, however at higher defoliation levels $(\geq 75 \%)$ it would appear that the trees are unable to compensate sufficiently to cope with the loss of photosynthetic surface. In a simulation of hail and typhoon damage in Korea, Han et al. (2016) defoliated 'Sinano Sweet' apple trees at monthly intervals and reported that fruit weight and yield decreased with increasing severity of defoliation; they concluded that defoliation time had a greater effect on carbohydrate reserves than degree of defoliation. While it is likely that fruit weight/size is influenced by both the degree and timing of damage, other factors such as temperature and incident radiation can also affect fruit size (Doud and Ferree, 1980; Wagenmakers and Callesen, 1995), and this may explain the difference in effect on fruit size in the first year trial. The rootstocks in this study varied between trials, but were all relatively vigorous rootstocks: MM106 in trials 1 and 3, and seedling and M1 in trials 2 and 4 respectively. This may also have influenced fruit size as it is well known that rootstock can influence fruit quality, however an examination of crop load and mean fruit weight data across the four trials suggests that crop load is more likely to have been the major influence on fruit weight. In the 'Delicious' trials, crop load in the controls was 3.9 fruit $\mathrm{cm}^{-2}$ TCSA in trial 1 and 6.5 fruit $\mathrm{cm}^{-2}$ TCSA in trial 2, with mean fruit weights of $181 \mathrm{~g}$ and $106 \mathrm{~g}$ respectively. A similar pattern was observed in trials 3 and 4 on the 'Gala', with crop loads of 10.69 and 20.9 fruit $\mathrm{cm}^{-2}$ TCSA and mean fruit weights of 120 and $81 \mathrm{~g}$. The same pattern is evident in both cultivars, with a reduction in fruit weight with increased crop load, regardless of rootstock.

Other reported effects of leaf damage caused by mites and other foliar feeders on apples include poor fruit colour, reduced sugar concentrations, and delayed maturity (Ames et al., 1984; Beers et al., 1987). In this study, complete defoliation advanced maturity in the 'Royal Gala', but this is most likely due to the very low crop load in this treatment. Effects on fruit firmness of 'Braeburn' by both whole and half-tree defoliation have also been reported (Davis et al., 2000). The work reported here confirmed previous reports that loss of leaf area can affect fruit firmness, but in addition, it also 
showed differences between cultivars. In 'Delicious' fruit firmness was reduced by high levels of leaf damage in both trials, however in 'Gala', there was an increase in fruit firmness with increasing levels of leaf damage. This agrees with the findings of Zwick et al. (1976) who reported differences between the cultivars 'Newtown' and 'Golden Delicious' when examining the impact of mite damage on fruit firmness.

This study showed some variation in the effect of leaf loss on fruit soluble solids concentrations. In the first year 'Delicious' trial, soluble solids were reduced following 100\% defoliation, while $50 \%$ leaf damage had no effect. This agrees with the findings of Marini et al. (1994) and Spieser et al. (1999) who reported that soluble solids concentration declined with increasing levels of mite damage. However, in this study subsequent trials showed an increase in fruit TSS with increasing levels of leaf damage up to two weeks after full bloom. There was also a reduction in TSS from 6 wAFB with the greatest reduction at $12 \mathrm{wAFB}$ at all defoliation levels. Hudina and Stampar (2000) reported decreased soluble solids in pear (Pyrus communis L.) with a $30 \%$ reduction in leaf area 4 weeks before harvest. Hence it appears that soluble solids concentration of fruit is affected by both level and time of leaf damage. In simulating defoliation by pests, DenHerder and Rom (1991) found that 50\% leaf removal 8 to 14 weeks after bloom had no effect on fruit soluble solids. It is however, difficult to explain the increased soluble solids with reduced leaf area; one explanation for this is an increase in fruit maturity brought about indirectly as a result of lower crop load levels in these treatments.

Although there was some variation with treatment effect on seed numbers in this study, there was a general trend towards higher seed numbers in treatments that resulted in low crop load, suggesting that seed number is important for fruit retention when resources are low. Healthy spur leaves early in the season appear to be important for seed development.

Reports on the effects of leaf damage on fruit background skin colour or starch levels are lacking. In this study, background skin colour and starch index ratings in 'Gala' suggested that greater foliar damage levels up to two weeks after flowering accelerated fruit maturity at normal harvest time. Both fruit background colour and starch levels are standard indicators of fruit maturity. This work suggests that damage to spur leaves from 1-2 weeks after full bloom tends to bring fruit maturity forward while high levels of defoliation from 9-12 wAFB can delay maturity.

Fruit length/diameter ratios were reduced in both 'Delicious' and 'Gala' by high levels of leaf damage, but there was no effect at low levels of damage. Fruit shape is important in all cultivars, but anything that affects fruit typiness of 'Delicious' apples can result in a major marketing disadvantage (Veinbrandts, 1979).

The results reported here have demonstrated that leaf damage during flowering may affect fruit quality to varying degrees, however the severity of the effect on fruit quality may depend on crop load. Both Marini et al. (1994) and Francesconi et al. (1996) reported greater decreases in fruit size, colour, and soluble solids concentration in damaged trees with heavy crops than in lightly cropped trees. Ames et al. (1984) also reported that deleterious effects of mite feeding increased with increasing fruit load. Zwick et al. (1976) suggested that vigorously growing, non-stressed apple trees were relatively tolerant of leaf damage by mites without adverse effects, and Hoyt et al. (1979) concluded that apple trees suffering from moisture stress were prone to ex- perience greater effects from mite injury. Hence, it is likely that healthy balanced trees will tolerate a higher level of leaf damage, whatever the cause, than stressed, poorly growing trees. It has also been postulated that the variation in results between individual studies may be due to differences in the environment, the timing and severity of mite stress, and the physiological status of the tree (Francesconi et al., 1996).

Reports on the effect of defoliation and/or leaf damage on return bloom are conflicting (Lienk et al., 1956; Beers et al., 1987; Beers and Hull, 1987; Hull and Beers, 1990; Lakso et al., 1996). Beers and Hull (1987) also reported differing responses between cultivars. The results of this work, where return bloom was generally higher where crop load was reduced, suggest that the level of return bloom may be related to crop load and is not necessarily a direct result of loss of leaf area up to 14 days after bloom. When leaf area is reduced at flowering, growth of new leaves ensures that the photosynthate supply is replaced before flower initiation for the following season occurs and thus explains why early season leaf damage has little or no impact on subsequent flowering. However, a reduction in leaf area later in the season did impact on return bloom and this is likely to be due to reduced photosynthate availability during flower initiation and differentiation. A positive correlation between carbohydrate reserves and return bloom was also reported by Han et al. (2016) who found that mid-season defoliation resulted in the lowest return bloom. Reduction of carbohydrate reserves during the critical flower initiation period has the potential to push the trees into an alternate bearing cycle.

Bourse leaf removal in this study inhibited return bloom while loss of spur leaves, particularly early in the season had little effect on return bloom. These results are supported by the findings of Proctor and Palmer (1991) that, while spur leaves were not necessary for flower initiation and expression, removal of bourse leaves had a dramatic effect in reducing return bloom in the three cultivars they studied. They also cited references by Ramirez (1979) and Hoad and Abbott (1986) showing that removal of bourse leaves of 'Cox' almost eliminated subsequent flowering. Work by Davis et al. (2000) and Elsysy and Hirst (2017) confirmed this finding.

This study has demonstrated that low levels of foliar damage have little effect on fruit size or quality, but high levels can impact on both set and quality. Trees are susceptible to damage during the period 6-12 weeks after full bloom which is the critical period for cell division in the fruit as well as flower initiation for the following year. High levels of leaf damage also reduced fruit size in spite of reduced crop load levels, most likely the result of a reduction in carbohydrate assimilation during the cell division phase of fruit development, but further research is needed to confirm this. It can be concluded that leaf damage occurring during flowering following the application of desiccants for blossom thinning will have little impact on fruit set or quality; however high levels of damage occurring later in the season may result in alternate bearing in addition to affecting fruit quality.

\section{Acknowledgments}

Thanks are due to Ms Caron Summers and Mr Shenan Daniels for technical assistance.

\section{References}

Ames, G.K., Johnson, D.T., and Rom, R.C. (1984). The effect of European red mite feeding on the fruit quality of 'Miller Sturdeespur' apple. J. Am. Soc. Hortic. Sci. 109, 834-837. 
Baïram, E., leMorvan, C., Delaire, M., and Buck-Sorlin, G. (2019). Fruit and leaf response to different source-sink ratios in apple, at the scale of the fruit-bearing branch. Front. Plant Sci. 10, 1039. https://doi. org/10.3389/fpls.2019.01039.

Beers, E.H., and Hull, L.A. (1987). Effect of European red mite (Acari:Tetranychidae) injury on vegetative growth and flowering of four cultivars of apples. Environm. Entomol. 16, 569-574.

Beers, E.H., Hull, L.A., and Grimm, J.W. (1987). Relationships between leaf:fruit ratio and varying levels of European red mite stress on fruit size and return bloom of apple. J. Am. Soc. Hortic. Sci. 112, 608-612.

Bound, S.A., and Jones, K.M. (1997). Investigating the efficacy of endothal as a chemical thinner of red 'Delicious' apple. J. Hortic. Sci. 72, 171-177. https://doi.org/10.1080/14620316.1997.11515503.

Bound, S.A., and Jones, K.M. (2004). Ammonium thiosulphate as a blossom thinner of 'Delicious' apple, 'Winter Cole' pear and 'Hunter' apricot. Austr. J. Exp. Agr. 44, 931-937.

Davis, D.E., Barden, J.A., and Byers, R.E. (2000). Defoliation affects return bloom, fruit set, and fruit quality of three apple cultivars (Abstract). HortScience 35, 482. https://doi.org/10.21273/ HORTSCI.35.3.482D.

DenHerder, M.A., and Rom, C.R. (1991). Carbohydrate content, spring growth and bloom of partially defoliated apple trees. HortScience 26, 174. https://doi.org/10.21273/HORTSCI.26.5.497g.

Doud, D.S., and Ferree, D.C. (1980). Influence of altered light levels on growth and fruiting of mature 'Delicious' apple trees. J. Am. Soc. Hortic. Sci. 105, 325-328.

Elsysy, M.A., and Hirst, P.M. (2017). The role of spur leaves, bourse leaves, and fruit on local flower formation in apple: An approach to understanding biennial bearing. HortScience 52(9), 1229-1232. https://doi.org/10.21273/HORTSCI12136-17.

Ferree, D.C., and Palmer, J.W. (1982). Effect of spur defoliation and ringing during bloom on fruiting, fruit mineral level, and net photosynthesis of 'Golden Delicious' apple. J. Am. Soc. Hortic. Sci. 107, 1182-1186.

Francesconi, A.H.D., Lakso, A.N., Nyrop, J.P., Barnard, J., and Denning, S.S. (1996). Carbon balance as a physiological basis for the interactions of European red mite and crop load on 'Starkrimson Delicious' apple trees. J. Am. Soc. Hortic. Sci. 121, 959-966. https:// doi.org/10.21273/JASHS.121.5.959.

Frappell, B.D., and O'Loughlin, J.B. (1962). The harvest and storage of pears. Tasmanian J. Agric. 33, 70-77.

Han, J.H., Han, H.H., Kwon, Y.H., Jung, J.H., Ryu, S., Do, K.R., Lee, H., Cjoi, I.M., and Kim, T. (2016). Effect of early defoliation on fruit yield, reserve accumulations and flower bud formation in 'Sinano Sweet' apple trees. Protected Hortic. Pl. Factory 25(2), 133-137. https:// doi.org/10.12791/KSBEC.2016.25.2.133.

Hoad, G.V., and Abbott, D.L. (1986). Hormonal control of growth and reproductive development in apple. In The Regulation of Photosynthesis in Fruit Trees, A.N. Laksom and F. Lenz, eds. Symposium Proceedings, NY State Agricultural Experimental Station, Geneva, NY, U.S.A., p. 87-92.

Hoyt, S.C., Tanigoshi, L.K., and Browne, R.W. (1979). Economic injury level studies in relation to mite on apple. Rec. Adv. Acarology 1, 3-12. https://doi.org/10.1016/B978-0-12-592201-2.50008-7.

Hudina, M., and Stampar, F. (2000). Influence of leaf area on the sugar and organic acids content in pear fruits (Pyrus communis L.) cv. 'Williams'. Eighth Int. Symp. on Pear, Ferrara-Bologna, Italy, 4-9 Sept. 2000.

Hull, L.A., and Beers, E.H. (1990). Validation of injury thresholds for European red mite (Acari:Tetranychidae) on 'Yorking' and 'Delicious' apple. J. Econ. Entomol. 83, 2026-2031. https://doi.org/10.1093/ jee/83.5.2026.
Irving, D.E., Pallesen, J.C., and Drost, J.H. (1989). Preliminary results on chemical thinning of apple blossoms with ammonium thiosulphate, NAA and ethephon. N. Z. J. Crop Hortic. 17, 363-365. https://doi.org/10.1080/01140671.1989.10428058.

Jones, K.M., Bound, S.A., Koen, T.B., and Oakford, M.J. (1992). Effect of timing of hand thinning on the cropping potential of red Fuji apple trees. Austr. J. Exp. Agr. 32, 417-420. https://doi.org/10.1071/ EA9920417.

Koen, T.B., Jones, K.M., and Longley, S.B. (1988). Spray thinning strategies for 'Red Delicious' apple using naphthalene acetic acid and ethephon. J. Hortic. Sci. 63, 31-35. https://doi.org/10.1080/146203 16.1988.11515824.

Kon, T.M., Schupp, J.R., Winzeler, H.E., and Marini, R.P. (2013). Influence of mechanical string thinning treatments on vegetative and reproductive tissues, fruit set, yield and fruit quality of 'Gala' apple. HortScience 48(1), 10-46. https://doi.org/10.21273/ HORTSCI.48.1.40.

Lakso, A.N., Mattii, G.B., Nyrop, J.P., and Denning, S.S. (1996). Influence of European red mite on leaf and whole-canopy carbon dioxide exchange, yield, fruit size, quality, and return cropping in 'Starkrimson Delicious' apple trees. J. Am. Soc. Hortic. Sci. 121, 954958. https://doi.org/10.21273/JASHS.121.5.954.

Lienk, S.E., Chapman, P., and Curtis Jr., O.F. (1956). Responses of apple trees to mite infestations. J. Econ. Entomol. 49, 350-353. https://doi. org/10.1093/jee/49.3.350.

Little, C. (1999). Apple and Pear Maturity Manual (Sherbrooke, Victoria, Australia: C.R. Little), 118 pp.

Llewelyn, F.W.M. (1963). The importance of spur leaves and limesulphur sprays on fruit retention in three apple varieties. Report East Malling Research Station for 1962, p. 89-92.

Llewelyn, F.W.M. (1966). The results of three years' spray and defoliation treatments, and their residual effects, on fruit retention in three apple varieties. Report East Malling Research Station for 1965 , p. $125-127$.

Llewelyn, F.W.M. (1968). The effect of partial defoliation at different times in the season on fruit drop and shoot growth in Lord Lambourne apple trees. J. Hortic. Sci. 48, 519-526. https://doi.org/1 $0.1080 / 00221589.1968 .11514278$.

Marini, R.P., Pfeiffer, D.G., and Sowers, D.S. (1994). Influence of European red mite (Acari:Tetranychidae) and crop density on fruit size and quality and on crop value of 'Delicious' apples. J. Econ. Entomol. 87, 1302-1311. https://doi.org/10.1093/jee/87.5.1302.

Martin, D., Lewis, T.L., and Cerny, J. (1964). Apple fruit cell numbers in relation to cropping alternation and certain treatments. Austr. J. Agr. Res. 15, 905-919.

Priestley, C.A. (1962). Carbohydrate resources within the perennial plant: Their utilisation and conservation. Techn. Commun. No. 27 (Farnham Royal, Bucks., England: Commonwealth Agricultural Bureaux). https://doi.org/10.1071/AR9640905.

Proctor, J.T.A., and Palmer, J.W. (1991). The role of spur and bourse leaves of three apple cultivars on fruit set and growth and calcium content. J. Hortic. Sci. 66, 275-282. https://doi.org/10.1080/00221 589.1991 .11516154 .

Quinlan, J.D. (1966). The effects of partial defoliation on the pattern of assimilate movement in an apple rootstock. Report East Malling Research Station for 1965, p. 128-129.

Ramirez, H. (1979). Effects of growth substances on some physiological processes in apple in relation to flower initiation. Thesis. (Bristol, U.K.: University of Bristol).

Southwick, S., Weis, K.G., and Yeager, J.T. (1996). Bloom thinning 'Loadel' cling peach with a surfactant. J. Am. Soc. Hortic. Sci. 121, 334-338. https://doi.org/10.21273/JASHS.121.2.334. 
Spieser, F., Graf, B., Hohn, H., and Hopli, H.U. (1999). Effects of high apple rust mite population densities on gas exchange, yield, fruit quality, tree growth and flower formation. Integrated Plant Protection in Orchards, IOBC/wprs Bulletin 22(6), 77-85.

Veinbrants, N. (1979). Growth regulator helps Delicious shapes. Fruit World and Market Grower, Jan., p. 10.

Wagenmakers, P.S., and Callesen, O. (1995). Light distribution in apple orchard systems in relation to production and fruit quality. J. Hortic. Sci. 70, 935-948. https://doi.org/10.1080/14620316.199 5.11515369 .

Zwick, R.W., Fields, G.J., and Mellenthin, W.M. (1976). Effects of mite population density on 'Newtown' and 'Golden Delicious' apple tree performance. J. Am. Soc. Hortic. Sci. 101, 123-125.

Received: Jan. 31, 2020

Accepted: Jul. 28, 2020

Address of author:

Sally A. Bound

Tasmanian Institute of Agriculture, University of Tasmania,

Private Bag 98, Hobart, Tasmania 7001, Australia

E-mail: sally.bound@utas.edu.au 